REVIEW ARTICLE

\title{
The challenge in paediatric sleep: What is normal?
}

\section{Suresh S, Parsley C}

Consultant Pulmologist, Sri Ramachandra Medical College and Research Institute, Porur, Chennai-600116

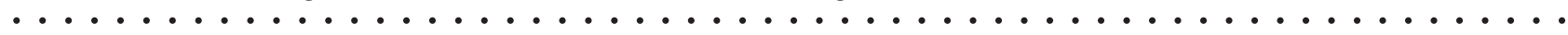

Indian J Sleep Med 2009; 4.2, 39-42

\begin{abstract}
Sleep is a universal phenomenon in the animal kingdom. The role of sleep in human beings has been studied with increasing interest over the last 60 years. This has resulted in increased awareness of sleep medicine as a separate entity. This review will focus on some of the aspects of paediatric sleep medicine: The physiology and function of sleep, development and maturity of sleep, parasomnias, behavioural aspects of children's sleep, normal values in polysomnography, spectrum of paediatric sleep disorders and its role in future morbidity of the individuals.

If sleep does not serve an absolutely vital function, then it is the biggest mistake the evolutionary process ever made. - Dr Alan Rechtshaffen, sleep research pioneer.
\end{abstract}

\section{The physiology and function of sleep}

S leep is defined as "a natural and periodic state of rest during which consciousness of the world is suspended". This is brought about by complex interactions between the reticular activating system and diffuse set of neuronal centres that facilitate different aspects of sleep. The most important factor appears to be the desynchronisation with the cortical centres that are related to consciousness. Sleep has been further differentiated with the help of electroencephalogram [EEG] and the current convention is EEG based staging of sleep. In infancy it is differentiated as active and quiet sleep (1) and as the development progresses characteristic features are noted and the sleep is broadly divided as Rapid Eye Movement [REM] and Non Rapid Eye Movement [NREM] sleep (2). The total amount of sleep from birth to adolescence is shown in fig $1 \& 2$.(3).

Address for correspondence

Suresh S, MBBS, MRCPCH, FRACP

Parsley C, B.Engg, RSPGT

Dept of Paediatric Respiratory/Sleep Medicine

Mater Children's Hospital

South Brisbane, 4101 Australia

Email: suresh@paedsleep.org
Although sleep has been studied extensively over the last few decades the exact function of sleep has not been fully

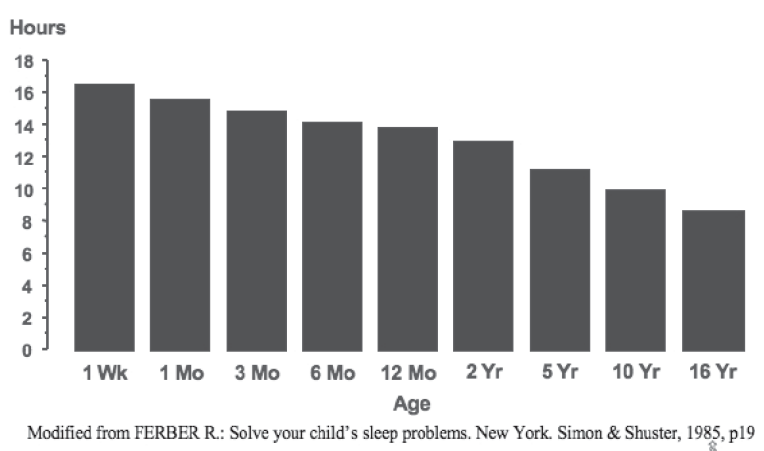

Figure 1: Total sleep time through the ages

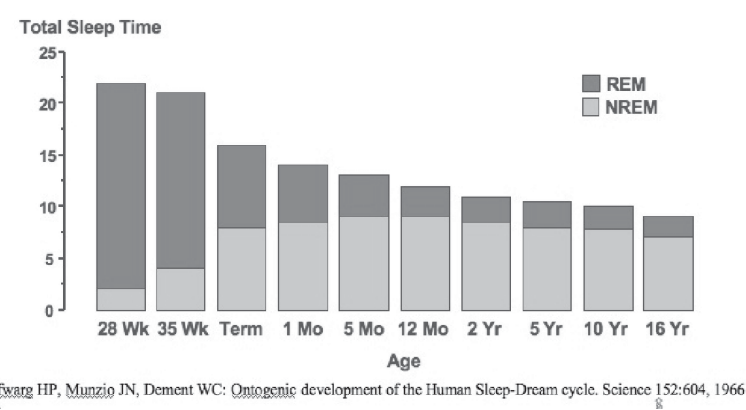

Figure 2: Total sleep time with REM/NREM split

Indian Journal of Sleep Medicine (IJSM), Vol. 4, No. 2, 2009 
discerned. However there is reasonable amount of information available to attribute the following functions to sleep (4-7):

1) Sleep is noted to restore and recuperate the human body to optimal day time functioning(restoration theory). NREM sleep is thought to function in reparation of body tissue and REM sleep in restoration of brain tissue $(8,9)$.

2) Sleep is considered a facet of evolutionary development and complexity of sleep is attributed to the complex nature of the human physiological system

3) Sleep centres are considered important in the process of learning and memory (learning theory) (10). The unlearning theory complements this process by handling the clutter of information and removing nonessential information in an orderly fashion, thereby facilitating enhanced learning.

\section{Development and maturity of sleep:}

Similar to many aspects of development, sleep also undergoes changes with age. The physiological aspects that evolve during the early years are maturation of the EEG, development of cardio respiratory reflexes, establishment of the circadian rhythm and consolidation of sleep architecture. Table 1 highlights the salient features (11). 95\% of infants cry with a night awakening which will need a parental response. By the age of 1 year $60-70 \%$ of these infants are able to go back to sleep on their own. The ability to selfsoothe and return to sleep is the most important aspect for consolidated sleep as awakenings are normal part of a night sleep even in adulthood. Self-sleep initiation is a learned phenomenon and is essential for establishment of sleep continuity. Sleep maturation is linked to intellectual development in children.

\section{Sleep phenomena or parasomnias in children}

Parasomnias are undesirable motor, autonomic or experiential phenomena that occur exclusively or predominantly during the sleep state(12). Parasomnias have sleep state related features and many of them are benign. The majority of these decreases in frequency as the child get older. Some of them exhibit familial links. Table 2 is a simplified summary of parasomnias with prevalence rates(13).

\section{Behavioural aspects of children's sleep}

Unlike adults, infants and young children do not present with problems in their sleep. The parents present their problem. It is important to properly evaluate the symptoms and assess if there is a sleep disorder present or just a variation of the normal. The treatment if any should be for the child primarily and not necessarily to fulfil parental desire. Age specific common non-respiratory sleep problems are tabulated in table 3(13)

Table 1: The developmental changes in sleep and sleep cycle organisation from the neonatal period to adult hood(11)

\begin{tabular}{|l|l|l|}
\hline & Infant & Adult \\
\hline $\begin{array}{l}\text { Sleep state proportion } \\
\% \text { REM/NREM }\end{array}$ & $50 / 50$ & $20 / 80$ \\
\hline $\begin{array}{l}\text { Periodicity of } \\
\text { sleep states }\end{array}$ & $50-60 \mathrm{~min}$ & $90-100 \mathrm{mins}$ \\
\hline Sleep onset stage & REM sleep onset & NREM sleep onset \\
\hline $\begin{array}{l}\text { Temporal } \\
\text { organisation of } \\
\text { sleep states }\end{array}$ & $\begin{array}{l}\text { REM-NREM cycles } \\
\text { equally throughout } \\
\text { sleep period }\end{array}$ & $\begin{array}{l}\text { NREM stages 3-4 } \\
\text { predominant in the } \\
\text { first third of night } \\
\text { REM stage predominant } \\
\text { in last third of night }\end{array}$ \\
\hline $\begin{array}{l}\text { Maturation of EEG } \\
\text { patterns }\end{array}$ & $\begin{array}{l}\text { LVF pattern } \\
\text { HVS pattern }\end{array}$ & $\begin{array}{l}\text { K complexes delta } \\
\text { waves }\end{array}$ \\
\hline $\begin{array}{l}\text { Concordance of } \\
\text { sleep measures } \\
\text { [organisation of } \\
\text { sleep states] }\end{array}$ & Poor & Good \\
\hline
\end{tabular}

Table 2: Parasomnias

\begin{tabular}{|l|l|l|l|}
\hline & NREM related & REM related & $\begin{array}{l}\text { Sleep State } \\
\text { Independent }\end{array}$ \\
\hline Normal & $\begin{array}{l}\text { Hypnogogic } \\
\text { Imagery } \\
\text { Sleep starts } \\
\text { Confusional } \\
\text { Arousals 17\% }\end{array}$ & $\begin{array}{l}\text { Dreams } \\
\text { Nightmare } \\
10-50 \%\end{array}$ & $\begin{array}{l}\text { Bruxism 28.1\% } \\
\text { Rhythmic movement } \\
\text { disorder 17.2\% } \\
\text { Sleep talking 55\% }\end{array}$ \\
\hline Abnormal & $\begin{array}{l}\text { Night terrors } \\
17.3 \%\end{array}$ & $\begin{array}{l}\text { Sleep paralysis } \\
\text { REM behaviour } \\
\text { Sleep walking } \\
\text { disorder }\end{array}$ & $\begin{array}{l}\text { Periodic leg } \\
\text { movement }\end{array}$ \\
\hline
\end{tabular}

Table 3: Non-respiratory sleep disorders

\begin{tabular}{|c|c|c|c|}
\hline $\begin{array}{l}\text { Infant/toddler } \\
{\left[\begin{array}{ll}1-2 & \text { yrs }\end{array}\right]}\end{array}$ & $\begin{array}{l}\text { Preschool } \\
{[3-5 \text { yrs }]}\end{array}$ & $\begin{array}{l}\text { Primary school } \\
{[6-12 \mathrm{yrs}]}\end{array}$ & $\begin{array}{l}\text { Adolescent } \\
{[13-18 \mathrm{yrs}]}\end{array}$ \\
\hline $\begin{array}{l}\text { - Behavioural } \\
\text { insomnia of } \\
\text { childhood } \\
\text { - Rhythmic } \\
\text { movement }\end{array}$ & $\begin{array}{l}\text { - Behavioural } \\
\text { insomnia of } \\
\text { childhood } \\
\text { - Sleep terrors } \\
\text { - Rhythmic } \\
\text { movement }\end{array}$ & $\begin{array}{l}\text { - Insufficient } \\
\text { sleep } \\
\text { - Bedtime } \\
\text { resistance } \\
\text { - Sleep } \\
\text { walking }\end{array}$ & $\begin{array}{l}\text { - Insufficient } \\
\text { sleep } \\
\text { - Delayed sleep } \\
\text { phase } \\
\text { - Narcolepsy }\end{array}$ \\
\hline
\end{tabular}




\section{Polysomnography in children:}

The main investigative tool in children with suspected sleep disorder is the polysmnography [PSG]. Similar to other branches of medicine the PSG is to be performed after obtaining a proper clinical history and examination. The PSG consists of multiple channels and would traditionally include EEG, EOG, EMG, thorax and abdominal respiratory bands, oronasal flow sensor, oxyhaemoglobin saturations, transcutaneous/end-tidal carbon-dioxide sensor +/-video monitoring. This helps in ascertaining sleep stages accurately and the nature and severity of sleep related breathing disorder, if any. Children are significantly different from adults and criteria for scoring vary with modified definition for abnormal thresholds(14-17). Varying forms of limited channel PSGs have been used and when carefully planned the information obtained is beneficial in managing paediatric sleep problems.

\section{Spectrum of paediatric sleep disorders}

The general physiological patterns seen as part of various sleep disorders in children for the most part is same as adults. Some differences exist mainly reflecting aspects of behaviour, psychology and development. The ICD classification include paediatric sleep disorders in its most recent version (18).

Children experience a broad range of sleep disturbances including sleep apnoea, insomnia, parasomnia, delayed sleep phase, narcolepsy, and restless legs, but their clinical presentation, evaluation, and management may differ from adults. Although snoring and sleep apnoea may be the most common indication for an overnight sleep study in a child, one quarter of children presenting to a sleep clinic for evaluation will have a second sleep diagnosis, which is often non-respiratory in nature. Especially in children, ruling out sleep apnoea is rarely the end point of the sleep evaluation. Clinicians involved in sleep medicine must be prepared to recognize, evaluate, and have management plans for sleep disorders across the lifespan of the patient.

\section{Snoring and obstructive sleep apnoea syndrome [OSA]}

Snoring and OSA is one of the outstanding examples of the seamless transition from a normal phenomenon to an abnormal pathology. Snoring is noted in at least $20 \%$ of paediatric population at any one stage and is considered benign when it is not associated with any other sleep symptomatology. This is called primary snoring or habitual snoring. William Osler in 1892 stated "At night the child's sleep is greatly disturbed, the respirations are loud and snorting, and there are sometimes prolonged pauses, followed by deep, noisy inspirations"(19). In spite of such lucid description the importance of OSA in children has only been recognised in the last 30 years. There is now consensus guidelines regarding diagnosis and management of paediatric obstructive sleep apnoea published by the American Academy of Paediatrics(20). The mainstay of treatment in the paediatric age group is adenotonsillectomy and the resolution rate is close to $90 \%$. In a small percentage of children OSA persists and will need further investigation and treatment. Treatment of underlying medical condition and control of weight gain contribute significantly in reducing the severity of OSA. Supportive therapy during sleep in the form of continuous positive airway pressure [CPAP] therapy has been proven to be beneficial similar to adult OSA patients.

\section{Complications of untreated OSA}

Severe forms of untreated OSA has been associated with cor pulmonale, developmental delay, failure to thrive or death. Over the last decade there has been increased understanding of the morbidity from untreated OSA, even when the OSA is in the mild to moderate category. There is also evidence emerging that primary snoring might not be as benign as thought to be and also be associated with some sequelae $(21,22)$. Neurocognitive and learning deficits have been associated with $\operatorname{OSA}(23)$ and early diagnosis and appropriate treatment appears to reverse some of the deficits. However in some children the changes appear irreversible and it is postulated the older the child at the age of treatment the lesser the chance of reversing the deficits (24). Further longitudinal studies are required to clearly delineate the longterm consequences of untreated OSA.

Untreated OSA in adulthood is associated with increased cardiovascular, cerebrovascular morbidity and it is likely that some of the changes have their origins in childhood (2527).

\section{Conclusions}

Sleep is a widespread biological phenomenon, and its scientific study is proceeding at multiple levels at the same time. Marked progress is being made in answering three fundamental questions: what is sleep, what are its mechanisms and what are its functions? 
Sleep is critical for health and is undervalued both in our $24 \mathrm{~h}$ society and in paediatric clinical practice. Sleep problems are extremely common during childhood, from infancy to adolescence. Despite the prevalence of sleep problems, childhood sleep disorders are often under recognized and undiagnosed, despite being either preventable or treatable. Sleep impacts almost all aspects of a child's functioning, and thus the increased recognition and treatment of sleep disorders will positively affect a child's well being.

\section{References}

1. Anders T, Emde R, Parmalee A. A manual of standardized terminology, techniques and criteria for scoring states of sleep and wakefulness in newborn infants: UCLA Brain Information Service, Brain Research Institute, Los Angeles, CA; 1971.

2. Rechtschaffen A, Kales, A A manual of standardized terminology: techniques and scoring system for sleep stages of human subjects. Brain Research Institute, UCLA, Los Angeles, CA: National Institutes of Health publication 2040; 1968.

3. Roffwarg HP, Muzio JN, Dement WC. Ontogenetic Development of the Human Sleep-Dream Cycle. Science. 1966 Apr 29;152(3722):604-19.

4. Wagner U, Gais S, Haider H, Verleger R, Born J. Sleep inspires insight. Nature. 2004 Jan 22;427(6972):352-5.

5. Waking up to the importance of sleep. Nature. 2005 Oct 27;437(7063): 1207

6. Hobson JA. Sleep is of the brain, by the brain and for the brain. Nature. 2005 Oct 27;437(7063):1254-6.

7. Mahowald $\mathbf{M W}$, Schenck $\mathrm{CH}$. Insights from studying human sleep disorders. Nature 2005 Oct 27;437(7063):1279-85.

8. Siegel JM. Clues to the functions of mammalian sleep. Nature. 2005 Oct 27;437(7063):1264-71.

9. Crick F, Mitchison $G$. The function of dream sleep. Nature. 1983 Jul 14-20;304(5922):111-4.

10. Stickgold R. Sleep-dependent memory consolidation. Nature. 2005 Oct 27;437(7063):1272-8.

11. Ferber R KM. Principle and Practice of Sleep Medicine in the Child. W B Saunders; 1995.

12. Diagnostic Classification Steering Committee. Rochester MN: American Sleep Disorder Association; 1990 Contract No.: Document Number.

13. Moore $\mathbf{M}$, Allison $\mathrm{D}$, Rosen $\mathrm{CL}$. A review of pediatric nonrespiratory sleep disorders. Chest. 2006 ct;130(4): 1252-62.

Indian Journal of Sleep Medicine (IJSM), Vol. 4, No. 2, 2009
14. Marcus CL, Omlin KJ, Basinki DJ, Bailey SL, Rachal AB, Von Pechmann WS, et al. Normal polysomnographic values for children and adolescents. Am Rev Respir Dis. 1992 Nov;146(5 Pt 1):1235-9.

15. Quan SF, Goodwin JL, Babar SI, Kaemingk KL, Enright PL, Rosen GM, et al. Sleep architecture in normal Caucasian and Hispanic children aged 6-11 years recorded during unattended home polysomnography: experience from the Tucson Children's Assessment of Sleep Apnea Study (TuCASA). Sleep Med. 2003 Jan;4(1):13-9.

16. Montgomery-Downs HE, O'Brien LM, Gulliver TE, Gozal D. Polysomnographic characteristics in normal preschool and early school-aged children. Pediatrics. 2006 Mar;117(3):741-53.

17. Grigg-Damberger M, Gozal D, Marcus CL, Quan SF, Rosen $\mathrm{CL}$, Chervin RD, et al. The visual scoring of sleep and arousal in infants and children. J Clin Sleep Med. 2007 Mar 15;3(2):201-40.

18. WHO. International Statistical Classification of Diseases and Related Health Problems 2007 [updated 2007 cited 2009 1st March 2009]; 10th Revision: [Available from: http://www.who.int/classifications/apps/ icd/icd10online/.

19. Osler W. Chronic Tonsillitis. The Principles and Practice of Medicine. New York: Appleton \& C0; 1892. p. pp 335-9.

20. Clinical practice guideline: diagnosis and management of childhood obstructive sleep apnea syndrome. Pediatrics. 2002 Apr;109(4):704-12.

21. O'Brien LM, Mervis CB, Holbrook CR, Bruner JL, Klaus CJ Rutherford J, et al. Neurobehavioral implications of habitual snoring in children. Pediatrics. 2004 Jul;114(1):44-9.

22. Urschitz MS, Eitner S, Guenther A, Eggebrecht E, Wolff J, Urschitz-Duprat PM, et al. Habitual snoring, intermittent hypoxia, and impaired behavior in primary school children. Pediatrics. 2004 Oct;114(4):1041-8.

23. Gozal D. Sleep-disordered breathing and school performance in children. Pediatrics. 1998 Sep;102(3 P 1):616-20.

24. Gozal D, Pope DW, Jr. Snoring during early childhood and academic performance at ages thirteen to fourteen years. Pediatrics. 2001 Jun;107(6):1394-9.

25. McNamara F, Sullivan CE. Pediatric origins of adult lung diseases. 3: the genesis of adult sleep apnoea in childhood. Thorax. 2000 Nov; 55(1 1):964-9.

26. Tauman R, Ivanenko A, O'Brien LM, Gozal D. Plasmo C-reactive protein levels among children with sleepdisordered breathing. Pediatrics. 2004 Jun; 113(6): e564-9.

27. Amin RS, Carroll JL, Jeffries JL, Grone C, Bean JA, Chini B et al. Twenty-four-hour ambulatory blood pressure in children with sleep-disordered breathing. Am J Respir Crit Care Med. 2004 Apr 15;169(8):950-6. 